There is a conflict between the 'ages' for the core given by the $7 \cdot 5-\mathrm{m}$ date and the remaining four dates for which no satisfactory explanation has been found. If the core represents only 22,000 years, as the $7 \cdot 5$-m date suggests, it nevertheless spans times when the Bering land bridge existed and when the Wisconsin glaciation reached its maximum 18,000 years ago ${ }^{1}$. If the $7 \cdot 5-\mathrm{m}$ date can be discarded, the four mutually supporting dates indicate a much longer history but the land bridgo and glacial periods are still included. On either chronology the pollen record strongly suggests that the continental lowlands north of the ice sheots, including the Bering land bridge, supported only treeless tundras. It follows that animals and men crossing the land bridge must have been able to withstand life in a cold, Aretic environment.

The work was supported by the U.S. National Science Foundation and was also assisted by units of the U.S. Air Force in Alaska.

Department of Zoology,

Duke University, Durham, N.C.

* Present address: Department of Botany, The Queen's University of Belfast.

'Flint, R. F., Glacial and Pleistocene Geology (Wiley, New York, 1957) ${ }^{2}$ Hopkins, D. M., Science, 129, 1519 (1959).

${ }^{s} 63^{\circ} 29^{\prime}$ N., $170^{\circ} 06^{\prime}$ W., Board on Geographic Names, U.S. Dept. Int. Decision List 6202 (1962).

${ }^{4}$ Livingstone, D. A., Ecol., 36, 587 (1955).

${ }^{5}$ Colinvaux, P. A., Ph.D. thesis, Duke University (Univ. Microftlms, Ann Arbor, Michigan, 1962).

\section{Anthoxanthum alpinum $A$. and D. Löve, New to the British Isles}

A GRAss, referable to Anthoxanthum alpinum $\mathrm{A}$. and D. Löve, has been collected from a snow patch in the Cairngorms near the Invernesshire-Aberdeenshire border. This species was described in $1948^{1}$ from Swedish Lappland on the basis of a few morphological characters which distinguish it from the widespread. Anthoxanthum odoratum L. because it also differed from that tetraploid species $(2 n=$ 20 ) in being a diploid $(2 n=10)^{2}$. It has an arctic-alpine type of distribution in northern Europe from Iceland to Finland and in the Swiss Alps. Tutin ${ }^{3}$ confirmed the diploid chromosome number in Swiss material and gave further morphological criteria for the separation of these species. He also suggested that Anthoxanthum alpinum might occur in the British Isles as it is readily confused with the widespread $A$. odoratum.

The British material conforms morphologically to the descriptions of Anthoxanthum alpinum A. and D. Löve but differs from the type in being $2 n=20$. This must raise doubts about the specific status of that plant.

\section{B. M. G. Jones}

Department of Botany,

Queen Mary College,

London, E.1.

${ }^{1}$ Löve, A., and Lobve, D., Univ. Reykjavik Inst. App. Sci. Dep. Agric. Rep. Ser. B., No. 3, 105 (1948).

- Östergren, G., Hereditas, 28, 242 (1942).

${ }^{3}$ Tutin, T. G., Watsonia, 1, 224 (1950).

\section{Settlement of Spirorbis borealis Daudin Larva on Surfaces bearing Films of Micro-organisms}

SURFACES newly immersed in the sea are quickly covered by a film of bacteria, diatoms, algae and flagellates. These micro-organisms may become attached within hours? while their relative numbers vary from place to place ${ }^{3,6}$.

The larvæ of benthic invertebrates will meet such films whenever they alight during the exploratory phases of settlement. These films are certainly capable of influencing settlement, for the larvæ of Ophelia bicornis Savigny ${ }^{4}$, Spirorbis borealis Daudin and Bugula flabellata
(Thompson) ${ }^{1}$ can all distinguish between substrates having a film and substrates lacking one.

Wilson ${ }^{5}$ has suggested that the different film-forming micro-organisms might vary in their ability to promote settlement. This hypothesis-not tested before-has been substantiated by the results described here.

Films developing on surfaces immersed in sea water promote settlement of Spirorbis borealis larvæ ${ }^{1}$. The following experiment shows that this effect can be obtained by soaking panels in sea water containing its natural suspended matter (including micro-organisms), but not in sea water from which this has been removed. A sampla of sea water was divided in two: half was filtered through an 'Oxoid' membrane filter of pore diameter $0 \cdot 5-1 \cdot 0 \mu$, and the particulate matter on the filter pad returned to an equivalent volume of membrane-filtered sea water. The other half was similarly filtered but the particulate matter discarded. Twenty slate panels, each measuring $5.0 \times 1.8$ $\mathrm{cm}$, were soaked for $12 \mathrm{~h}$ in the two solutions, ten in one and ten in the other. After soaking, these were arranged radially around the bottom of a circular glass dish, diameter $34 \mathrm{~cm}$, containing 9-10 l. sea water. Larvæ of Spirorbis borealis Daudin, obtained by methods similar to those used by Knight-Jones ${ }^{2}$, were added to the dish, which was then slowly rotated under constant overhead illumination. Iight intensity at the water surface varied between 450 and 650 lux in different experiments. After $12 \mathrm{~h}$, when most of the larvæ had settled, the panels were removed. Of those which had settled, 348 were counted on the film previously developed in the presence of the resuspended particulate matter, and 29 on that previously developed in the membrane-filtered sea water.

Table 1. SETtLement on Panels Fllmed WITH DIFFERent CoMponents OF THE PRIMARY FILM

Panel treatment

No. of Concentration of larve organisms in the settled cultures after ? days (cells/ml.)

Panels previously soaked in:

Dunaliella galbana culture

(a) Culture previously in natural daylight-

(b) Culture previously in total darkness for 7 days

Navicula $\mathrm{sp}$.

(a) Culture previously in natural daylightdarkness regime for 7 days Culture

Mixed diatom culture

(a) Culture previously in natural daylightdarkness for 7 days

(b) Culture previously in total darkness for 7 days

Membrane-filtered sea-water

(a) Previously in natural daylight-darkness régime for 7 days
Previously in total darkness for 7 days

$\begin{array}{rr}15 & 5 \times 10^{4} \\ 227 & 5 \times 10^{3} \\ 2,098 & 8 \times 10^{4} \\ 754 & <3 \times 10^{2} \\ 1,548 & 8 \times 10^{4} \\ 461 & 3 \times 10^{3} \\ 481 & <3 \times 10^{2} \\ 447 & <3 \times 10^{2}\end{array}$

The effect on settlement of some micro-organisms which may occur in natural films was then tested. $16 \mathrm{l}$. of sea water collected from the Menai Straits were membranefiltered, pasteurized, and then divided into eight 2-1. aliquots. Two of these were inoculated from a uni-algal culture of Dunaliella galbana, two from a population of mixed Navicula sp., and two from a mixed population of diatoms; the remaining two were not inocnlated. One of each of these four pairs was then kept under a natural day-night régime for seven days, and the other in total darkness. Counts at the end of 7 days showed large numbers of the respective organisms in the cultures previously kept in daylight, and very small numbers in cultures kept in darkness (Table 1). The mixed diatoms included Ceratium, Chaetoceros, Navicula, Nitschia and Skeletonema sp. Neither of the two samples of membranefiltered sea water showed any growth of diatoms or green flagellates at the end of the 7-day period. 32 slate panels were divided into 8 groups, each of 4 panels. The 8 groups were then soaked for $12 \mathrm{~h}$, one group in each of the 8 cultures. Following this, the panels were transferred to a 